ECONOMICS

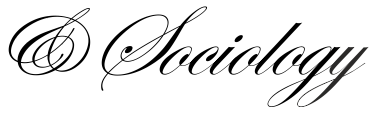

Sayanti Shaw,

Tomas Bata University in Zlin,

Zlin, Crech Republic,

E-mail:sayantishan@gmail.com, shan@fame.utb.cz.

Miloslava Chovancová, Tomas Bata University in Zlin, Zlin, Czech Republic,

E-mail:chovancova@fame.utb.cz.

Jiří Bejtkovský,

Tomas Bata University in Zlin,

Zlin, Crech Republic,

E-mail:bejtkovsky@fame.utb.cr.

Received: January, 2017

1st Revision: April, 2017

Accepted: August, 2017

DOI: $10.14254 / 2071-$

789X.2017/10-3/7

JEL Classification: M31
Shaw, S., Chovancová, M., Bejtkovský, J. (2017). Consumer Behaviour and Warranty Claim: A Study on Czech Consumers. Economics and Sociology, 10(3), 90101. doi:10.14254/2071-789X.2017/10-3/7

\section{CONSUMER BEHAVIOUR AND WARRANTY CLAIM: A STUDY ON CZECH CONSUMERS}

\begin{abstract}
Consumer behaviour concerning warranty is significant for both consumers and business entities. This article presents the behaviour of consumers on warranty claims for purchased products or services. The present study attempts to investigate the influence of demographic variables on consumer satisfaction in the course of the warranty claim procedure. To study the behaviour of consumers, a quantitative approach was adopted with the sample of 453 respondents in Czech Republic. A self-administered, structured questionnaire was used to collect primary data during the survey and analysis was performed using Statistical Package for Social Science (SPSS). This study contributes to the body of knowledge in the field of consumer behaviour concerning warranty claims.
\end{abstract}

Keywords: consumer behaviour, warranty claim, products, services

\title{
Introduction
}

Customer-oriented business strategies are increasingly gaining importance in today's highly competitive marketplace. Therefore, deep understanding of consumers' needs and expectations is becoming crucial for the development of effective business strategies. Consumer behaviour concerning warranty claim captures consumer's attitudes, preferences, intentions and decisions regarding his/her claim for repair, replacement or refund from a product or service provider, in the case of non-performance or underperformance of a product or a service. Effective handling of consumers' warranty claims can be beneficial to the firm due to several reasons, such as preventing loss of consumers; revealing actual problems related to the product or service; providing opportunities for product or service improvement as well as marketing programmes improvement; providing information to improve consumer satisfaction; giving ideas about new product or service concepts; protecting the trade or service mark; preventing negative word of mouth (WOM) communication about the product or service to other, potential customers. Consumer satisfaction is the consumers' perceived relation of expectation and the performance of products and services. If consumer experiences with a product are higher than or equal to the expected, then the customer is satisfied, otherwise dissatisfaction emerges (Schiffman \& Kanuk, 2000). Consumer satisfaction is reliant on the level to which a product perceived performance equals consumer expectations. If the product performance surpasses or equals expectations, the consumer is satisfied. On the other hand, level of dissatisfaction can be expressed as the result of the discrepancy between expected and realised performance of a product/service. If product 
performance falls short of expectations, the consumer is dissatisfied. During consumption or possession of goods or services, perceived dissatisfaction by consumers may turn into complaints against the failed goods or services. Customers' complaints may or may not be paired with a demand for redress. However, if consumers seek redress and the purchased goods or services are within the warranty period, that may lead them to claim the warranty for purchases, i.e. get repair, replacement or refund for the failed goods or services.

\section{Literature review}

A consumer complaint is defined as an action taken by an individual which involves communicating something negative regarding a product or service (Jacoby \& Jaccard, 1981). Moreover, the concept of consumer complaint behaviour can be expressed as a set of multiple responses, some or all of which are triggered by perceived dissatisfaction with a purchase period. The research area of consumer complaint behaviour deals with identification and analysis of all aspects involved in consumer reaction to a product or a service failure and the consequent perceived dissatisfaction (Garín-Muñoz et al., 2016). Several studies have been done to enrich the knowledge base concerning consumer complaint behaviour (Casado et al., 2011; Liu \& McClure, 2001; Mattila \& Wirtz, 2004; Singh, 1988). Many previous studies have been conducted to study the factors related to complaint behaviour, i. e. personal, service, situational and macrofactors (Baker et al., 2013; Ekinci et al., 2016; Hansen et al., 2010; Huppertz, 2003; Jin, 2010; Kanousi, 2005; Moliner Velázquez et al., 2010; Swanson et al., 2011). The issue of consumer complaint behaviour is dynamic and has tendency to change with respect to place, time and sector. Various previous studies have been done to assess the relationship between complaint behaviour and demographic variables such as age, gender, education, income. Demographic variables play significant roles in determining customer complaint behaviour (Li, 2010; Ndubisi \& Ling, 2006). It was found that demographic factors such as age, gender, and education level play a very important role in customer complaint behaviour (Day, 1976; Heung \& Lam, 2003; Keng et al., 1995; Volkov et al., 2002). In order to retain the existing customers and convert them to loyal ones, organisations must handle customers' complaints effectively and efficiently. In managing customers' complaints, it becomes strategically important to identify complaint behaviour differences related to customers. According Horáková (2015) university students with lower income are highly influenced by marketing tools such as price and various forms of discounts. From literature, it has been observed that consumers with different demographic attributes have different complaint behaviour. In this viewpoint, demographic characteristics play a significant role in determining complaint behaviour differences among consumers. Hence analysing consumers' complaint behaviour according to their demographic characteristics is an important part of consumer complaint management. However, there is no consensus on the effect of age, income and education on complaint behaviour (Boote, 1998; Broadbridge \& Marshall, 1995; Hogarth et al., 2001). It is stated that younger customers are more likely to complain than elder ones (Day, 1977; Grougiou \& Pettigrew, 2009; Heung, 2000; Jacoby \& Jaccard, 1981; Nimako \& Mensah, 2012; Singh, 1989). Conversely, a positive relation was found between age and complaint behaviour (Phau \& Baird, 2008). Most of the studies have found that consumers with higher education are more inclined to complain (Andreasen, 1988; Heung \& Lam, 2003; Williams, 2002). Nevertheless, people who have higher education level are less likely to complain as compared to those with lower education level (Phau \& Baird, 2008). Many studies suggest a positive link between income and complaint behaviour (Tronvoll, 2007). However, lower income and education group have been identified as having most problems in unfair deals and deceptions in the market compared to the other consumer groups (Haron \& Paim, 2008; Mahayudin et al., 2010). Nonetheless, there is no significant relationship between income and 
complaint behaviour (Metehan \& Zengin, 2011; Phau \& Baird, 2008). Females are more inclined to complain than males (Chan et al., 2016; Heung \& Lam, 2003; Keng et al., 1995). On the contrary, males are more inclined to complain than females, according to (Ngai et al., 2007). At the same time, no significant relationship between females and males with respect to complaint behaviour was observed in (Metehan \& Zengin, 2011; Phau \& Baird, 2008).

Table 1. Influence of demographic characteristics on the consumer complaint behaviour in literature

\begin{tabular}{|c|c|c|c|}
\hline Author(s) & $\begin{array}{l}\text { Demographic } \\
\text { attributes }\end{array}$ & Design/Context/Approach & Findings \\
\hline $\begin{array}{l}\text { Chan et al. } \\
\text { (2016) }\end{array}$ & $\begin{array}{l}\text { Sex, age, } \\
\text { education } \\
\text { level and } \\
\text { employment } \\
\text { level }\end{array}$ & $\begin{array}{l}\text { In-depth interviews were } \\
\text { conducted with semi- } \\
\text { structured questions to } 30 \\
\text { dissatisfied customers } \\
\text { (purposive sampling) who } \\
\text { frequently have their meal in } \\
\text { Asian full-service restaurants }\end{array}$ & $\begin{array}{l}\text { In comparison to male, female } \\
\text { customers intend to complain more. } \\
\text { Customers having a high educational } \\
\text { level in place of complaining tend not to } \\
\text { revisit the restaurant. }\end{array}$ \\
\hline $\begin{array}{l}\text { Nimako \& } \\
\text { Mensah } \\
\text { (2012) }\end{array}$ & $\begin{array}{l}\text { Gender, age, } \\
\text { education } \\
\text { level, income } \\
\text { and marital } \\
\text { status }\end{array}$ & $\begin{array}{l}\text { A cross-sectional survey } \\
\text { with self-administered } \\
\text { structured questionnaire } \\
\text { was conducted with } 480 \\
\text { customers (convenient } \\
\text { sampling) from four } \\
\text { prominent mobile operators } \\
\text { in Ghana. }\end{array}$ & $\begin{array}{l}\text { Demographic variables such as marital } \\
\text { status and age show significant influence } \\
\text { on complaint behaviour. Whereas, } \\
\text { gender, income and education show no } \\
\text { significant effect. Married and older } \\
\text { respondents are inclined to complain } \\
\text { less in comparison to younger and } \\
\text { unmarried ones. }\end{array}$ \\
\hline $\begin{array}{l}\text { Metehan \& } \\
\text { Zengin } \\
(2011)\end{array}$ & $\begin{array}{l}\text { Age, income, } \\
\text { education, } \\
\text { occupation, } \\
\text { family size } \\
\text { and gender }\end{array}$ & $\begin{array}{l}\text { Face to face surveys were } \\
\text { conducted at various } \\
\text { quarters of Ankara city } \\
\text { (Turkey) involving } 762 \\
\text { customers. }\end{array}$ & $\begin{array}{l}\text { No significant relationship was found } \\
\text { between complaint behaviour and } \\
\text { demographic characteristics such as } \\
\text { gender and income. On the other hands, } \\
\text { a positive correlation was found between } \\
\text { complaint behavior and demographic } \\
\text { attributes of occupation level and age. }\end{array}$ \\
\hline $\begin{array}{l}\text { Grougiou } \\
\& \\
\text { Pettigrew, } \\
(2009)\end{array}$ & Age & $\begin{array}{l}\text { In-depth (semi-structured) } \\
\text { interviews and projective } \\
\text { exercises were conducted with } \\
60 \text { customers facing negative } \\
\text { experiences in service. }\end{array}$ & $\begin{array}{l}\text { Aged customers are less intended and } \\
\text { avoid voicing their dissatisfaction. }\end{array}$ \\
\hline $\begin{array}{l}\text { Phau \& } \\
\text { Baird } \\
(2008)\end{array}$ & $\begin{array}{l}\text { Age, gender, } \\
\text { income and } \\
\text { education }\end{array}$ & $\begin{array}{l}\text { Mail }(1,200) \text { surveys were } \\
\text { conducted resulting in } 157 \\
\text { respondents having } \\
\text { unsatisfactory experience } \\
\text { within last } 12 \text { months. }\end{array}$ & $\begin{array}{l}\text { The study states that respondents with } \\
\text { tertiary education are less inclined to } \\
\text { complain in comparison to those without. } \\
\text { No significant relationship was found } \\
\text { between complaint behaviour and } \\
\text { demographic characteristics such as } \\
\text { gender and income. On the other hands, } \\
\text { positive relation was found between } \\
\text { consumer complaint behaviour and age. }\end{array}$ \\
\hline $\begin{array}{l}\text { Ngai et al. } \\
\text { (2007) }\end{array}$ & $\begin{array}{l}\text { Gender, } \\
\text { educational } \\
\text { level and age }\end{array}$ & $\begin{array}{l}\text { Face-to-face interview } \\
\text { survey with questionnaire } \\
\text { was conducted by involving } \\
271 \text { visitors who had } \\
\text { previous experience of } \\
\text { staying in Hong Kong hotels. }\end{array}$ & $\begin{array}{l}\text { Older and male consumers intend to } \\
\text { complain more publicly. Whereas, well- } \\
\text { educated respondents are less inclined to } \\
\text { complain publicly. }\end{array}$ \\
\hline
\end{tabular}




\begin{tabular}{llll}
\hline & & $\begin{array}{l}\text { A survey with self- } \\
\text { administered questionnaire } \\
\text { was conducted by involving }\end{array}$ & $\begin{array}{l}\text { Significant relationship was found } \\
\text { between complaint intention and } \\
\text { demographic variables such as age, } \\
\text { Heung \& } \\
\text { Lam (2003) }\end{array}$ \\
$\begin{array}{l}\text { and } \\
\text { educational } \\
\text { level }\end{array}$ & $\begin{array}{l}\text { (systematic random } \\
\text { sampling) of six Hong Kong } \\
\text { hotel restaurants. }\end{array}$ & $\begin{array}{l}\text { gender, and educational level. Well- } \\
\text { educated, young and female consumers } \\
\text { are more inclined to complain. }\end{array}$ \\
\hline
\end{tabular}

Source: compiled by the authors.

A firm's complaint handling activities can involve restitution and compensation in the form of reimbursement, product/service replacement, credit, apology, repair, refund, and correction. Warranty claim can be stated as customer's claim for replacement, repair or compensation for the failed product or service. Consumer complaint behaviour has received considerable attention from researchers, scholars, and practitioners. Several studies have been conducted to cover different issues related to customer complaint behaviour. However, one of the aspects that has been overlooked is consumer behaviour regarding warranty claim. The novelty of this article lies in the aspect of providing basic empirical evidence of the effect of demographic variables on consumer satisfaction with warranty claim procedure in the context of the Czech Republic. Proper (improper) handling of consumers' warranty claims, arising as a result of product or service failures, may have far-reaching positive (negative) consequences for the firm's relationship with its customers (Shaw, 2017). Taking into account, the huge cost of losing a customer that surpasses the expense of making corrections or any settlements in handling customers' warranty claims, it turns out to be crucially important for companies to understand consumer behaviour in the matter of warranty claim and the relationship between consumer satisfaction with warranty claim procedure and demographic features of consumers. Theoretical and empirical research papers mentioned in the literature review serve as the empirical basis of our current research.

\section{Objectives and Methodology}

\subsection{Research objectives}

This article reports a study on consumer behaviour concerning warranty claim in the Czech Republic. To gain a better understanding of such behaviour, the objectives of this study are threefold:

i. To observe demographic characteristics of respondents.

ii. To study features of consumer behaviour concerning warranty claim.

iii. To investigate whether there is a difference in consumer satisfaction with warranty claim procedure with respect to demographic variables.

The following hypotheses were developed to analyse the influence of demographic variables on consumer satisfaction with warranty claim procedure.

H1: There is no significant difference in consumer satisfaction with warranty claim procedure with respect to age.

H2: There is no significant difference in consumer satisfaction with warranty claim procedure with respect to highest level of education achieved.

H3: There is no significant difference in consumer satisfaction with warranty claim procedure with respect to net household income per single person /month.

H4: There is no significant difference in consumer satisfaction with warranty claim procedure with respect to gender. 


\subsection{Sampling}

This study investigates the behaviour of Czech customers regarding warranty claim, toward purchased products or availed services. In this study, consumer durable goods, consumer non - durable goods and consumer services are taken into account. A survey was performed by authors, with questionaries to collect data in the Czech Republic during November 2016 - January 2017 and subsequently analysis was performed. A quantitative approach was adopted with a sample size of 453 respondents, to study the behaviour of respondents in the matter of warranty claim. The sample of consumers were selected by simple random sampling method. The population of this study is 10.56 million $(10,560,000)$, which is the total population of the Czech Republic in the year 2016. For determining the sample size, the Yamane formula has been adopted, i.e. $\mathrm{n}=\mathrm{N} /\left(1+\mathrm{Ne}^{2}\right)$, where, $\mathrm{n}=$ required size of sample; $\mathrm{N}=$ population size; and $\mathrm{e}=$ margin of error. Therefore the required sample size for this study is:

$$
\begin{aligned}
& \mathrm{n}=10,560,000 /\left\{1+10,560,000 *(0.05)^{2}\right. \\
& \mathrm{n}=399.98 \approx 400
\end{aligned}
$$

With $\mathrm{N}=10,560,000$ and $\mathrm{e}=5 \%(95 \%$ confidence level), the required sample size is 400. Considering the fact that some questionnaires cannot be used due incomplete, invalid or no responses, a total of 550 questionnaires were distributed. Finally, 453 questionnaires were selected and used for further analysis. With a sample size of 453 respondents, the sampling error or the level of precision is $4.6 \%$. The survey was intended to get data related to warranty claim issues.

\subsection{Data collection}

A self-administered, structured questionnaire was used to collect primary data from consumers in the Czech Republic, during a survey programme. The survey questionnaire was comprised of three sections and had closed-ended questions. The first segment contained information about respondents' demographic profile i.e. age, gender, net household income per single person /month and the highest level of education achieved. The second part consisted of questions related to features of consumer behaviour concerning warranty claim such as frequency of claimed goods or services based on warranty in past two years, the minimum value of goods for warranty claim, source of information about the warranty claim procedure, and preferred mode for warranty claim settlement.

The third section was focused on determining respondents' satisfaction with warranty claim procedure. This segment was measured in five-point Likert scale $(1=$ Strongly disagree; $2=$ Disagree; $3=$ Neither agree nor disagree; $4=$ Agree; $5=$ Strongly agree). In this part, five scale items were used to measure consumer satisfaction with warranty claim procedure. The consumer satisfaction with warranty claim procedure was assessed as the average score of the five scale items, that allows an overall 'consumer satisfaction with warranty claim procedure' score to be calculated; a higher score indicates higher satisfaction with warranty claim procedure.

\subsection{Methods of data analysis}

The IBM Statistical Package for Social Science (SPSS) Statistics' Version 23 was used to analyse the data collected from the survey. Data were analysed using Descriptive Statistics, Cronbach's alpha, Independent-samples t-test, and One-way analysis of variance (ANOVA). 


\section{Results and Discussion}

\subsection{Demographic profile of respondents}

The demographic attributes of respondents such as age, gender, net household income per single person/month, and the highest level of education achieved are presented in Table 2 .

Table 2. Respondents' demographic profile

\begin{tabular}{|c|c|c|c|}
\hline \multirow{2}{*}{ Demographic variable } & \multirow{2}{*}{ Category } & \multicolumn{2}{|c|}{ Total Sample Size $=453$} \\
\hline & & Number & Percentage (\%) \\
\hline \multirow[t]{2}{*}{ Gender } & Female & 258 & 57.0 \\
\hline & Male & 195 & 43.0 \\
\hline \multirow[t]{5}{*}{ Age } & $18-24$ years & 267 & 58.9 \\
\hline & $25-34$ years & 85 & 18.8 \\
\hline & $35-49$ years & 66 & 14.6 \\
\hline & $50-65$ years & 26 & 5.7 \\
\hline & 66 years and more & 9 & 2.0 \\
\hline Highest level of & Basic & 17 & 3.8 \\
\hline \multirow[t]{3}{*}{ education achieved } & Vocational certificate & 48 & 10.6 \\
\hline & High school with maturita exam & 298 & 65.8 \\
\hline & University & 90 & 19.9 \\
\hline Net household income & Upto $5000 \mathrm{CZK}$ & 29 & 6.4 \\
\hline \multirow[t]{3}{*}{ per single person/month } & $5001-10000 \mathrm{CZK}$ & 128 & 28.3 \\
\hline & $100001-20000 \mathrm{CZK}$ & 222 & 49.0 \\
\hline & $20001 \mathrm{CZK}$ and more & 74 & 16.3 \\
\hline
\end{tabular}

Source: authors' research.

It can be observed from Table 2, in terms of gender, there were slightly more females $(57.0 \%)$ than males $(43.0 \%)$. Looking at age distribution, most of the respondents were in the age group of $18-24$ years $(58.9 \%)$, followed by those in the age groups $25-34$ years $(18.8 \%)$ and $35-49$ years $(14.6 \%)$, while fewer were in the age groups 50-65 years $(5.7 \%)$ and 66 years and more $(2.0 \%)$. Consequently, most of the respondents consist of young and middle-aged consumers. The education backgrounds of the respondents i.e. 'highest level of education achieved' showed $3.8 \%$ with basic level of education, $10.6 \%$ had vocational certificate, whereas, the majority of the respondents $(65.8 \%)$ had attained high school with maturita exam. However, the percentage of respondents with university level education is $19.9 \%$. For 'net household income per single person/month' category, most of the respondents were in the income group of 10001-20000 CZK (49.0\%), followed by those in the income groups 5001$10000 \mathrm{CZK}(28.3 \%)$ and $20000 \mathrm{CZK}$ and more (16.3\%), whereas, few were in the income group of up to $5000 \mathrm{CZK}(6.4 \%)$. From all these findings, it can be understood that data were obtained from a sample that represents different demographic characteristics.

\subsection{Features of consumer behaviour concerning warranty claim}

Table 3 represents the frequency of claimed goods or services based on warranty in past two years with respect to the percentage (as a share in total) of respondents. The percentage of the respondents who had claimed goods or services in past two years once, twice, and thrice are $26.7 \%, 27.6 \%$ and $21.2 \%$ respectively with the percentage of respondents claiming goods or services twice being the highest, as shown in Table 3. 
This is followed by $15.0 \%$ of the respondents, who had claimed goods or services in past two years four times or more. Comparatively, there were few respondents $(9.5 \%)$, who had not claimed any good or service in past two years' period.

Table 3. Frequency of claimed goods or services

\begin{tabular}{lc}
\hline Frequency of claimed goods or services & Percentage $(\%)$ \\
\hline Never & 9.5 \\
\hline Once & 26.7 \\
\hline Twice & 27.6 \\
\hline Thrice & 21.2 \\
\hline Four times or more & 15.0 \\
\hline
\end{tabular}

Source: authors' research.

The minimum value of goods for which the respondents would proceed for warranty claim, relating to the percentage (as a share in total) of respondents is presented in Table 4 . From Table 4, the majority of the respondents $(34.0 \%)$ would proceed for warranty claim when the minimum value of goods is $500 \mathrm{CZK}$. However, there were $31.3 \%$ of respondents, who would proceed for warranty claim without caring about the value of goods. Moreover, about $14.8 \%$, and $12.1 \%$ of the respondents would proceed for warranty claim when minimum value of goods are $1000 \mathrm{CZK}$ and $200 \mathrm{CZK}$ respectively. Followed by few, i.e. $3.5 \%$ and $2.9 \%$ of the respondents, who would advance for warranty claim when minimum value of goods are $100 \mathrm{CZK}$ and $1000 \mathrm{CZK}$ respectively. In comparison, there were very few number of respondents, i.e., $0.4 \%$ of the respondents, who would not proceed for warranty claim regardless of the value.

Furthermore, there were $0.9 \%$ of respondents who for the category of 'the minimum value of goods for warranty claim' had chosen the other amount option, in place of those mentioned in the survey questionnaire.

Table 4. Minimum value of goods

\begin{tabular}{lc}
\hline Minimum value & Percentage $(\%)$ \\
\hline Do not care about value & 31.3 \\
\hline $100 \mathrm{CZK}$ & 3.5 \\
\hline $200 \mathrm{CZK}$ & 12.1 \\
\hline $500 \mathrm{CZK}$ & 34.0 \\
\hline $1000 \mathrm{CZK}$ & 14.8 \\
\hline $2000 \mathrm{CZK}$ & 2.9 \\
\hline Other amount & 0.9 \\
\hline Goods not claimed & 0.4 \\
\hline
\end{tabular}

Source: authors' research.

Table 5 describes the 'source of information about the warranty claim procedure' category in relation to the number of respondents. In this category, respondents were allowed to choose more than one option. When respondents would like to find information about the warranty claim procedure, most of them $(\mathrm{N}=371)$ would take the help of internet, which is the most popular option among the respondents, as observed from Table 5. This is followed by the respondents $(\mathrm{N}=183)$ who would like to rely on their family, friends or relatives' experiences in order to get information about the warranty claim procedure. Legislation and print appear to 
be less important, with number of respondents choosing these options being 57 and 27 respectively. Chosen by only 4 respondents, the least important option in the category of 'source of information about the warranty claim procedure' is others.

Table 5. Source of information about the claim procedure

\begin{tabular}{lc}
\hline Source of Information & Frequency $(\mathrm{N})$ \\
\hline Internet & 371 \\
\hline Print & 27 \\
\hline Family, friends or relatives' experiences & 183 \\
\hline Legislation & 57 \\
\hline Others & 4 \\
\hline
\end{tabular}

Source: authors' research.

Table 6 shows preferred mode for warranty claim settlement relating to the percentage (as a share in total) of respondents. According to Table 6, the majority of the respondents $(64.9 \%)$ would prefer money back during warranty claim settlements. In addition, $21.6 \%$ of the respondents, would prefer exchange of goods for new ones. However, about $8.2 \%$ and $5.3 \%$ of the respondents would prefer repair of goods and exchange of goods for different goods respectively.

Table 6. Preferred mode for claim settlement

\begin{tabular}{lc}
\hline Preferred Mode & Percentage $(\%)$ \\
\hline Money back & 64.9 \\
\hline Exchange of goods for new & 21.6 \\
\hline Repair goods & 8.2 \\
\hline Exchange for different & 5.3 \\
\hline
\end{tabular}

Source: authors' research.

\subsection{Relationship between demographic attributes and consumer satisfaction with warranty claim procedure}

According to the reliability analysis, the Cronbach's alpha value (0.741) suggests that five scale items used to measure consumer satisfaction with warranty claim procedure had acceptable and reliable internal consistency.

ANOVA was used to analyse the relationship between demographic characteristics (like age, net household income per single person /month, and the highest level of education achieved) and consumer satisfaction with warranty claim procedure. Whereas, independentsamples t-test was used to analyse the relationship between gender and consumer satisfaction with warranty claim procedure. The results of ANOVA are shown in Table 7.

Table 7. Results of one-way analysis of variance (ANOVA)

\begin{tabular}{lccc}
\hline Hypothesis & F value & $\mathrm{p}$ value & Results \\
\hline Age & 16.612 & $<0.05$ & Rejected \\
\hline Education & 7.324 & $<0.05$ & Rejected \\
\hline Income & 0.064 & $>0.05$ & Accepted \\
\hline
\end{tabular}

Source: authors' research. 
ANOVA was conducted to determine if consumer satisfaction with warranty claim procedure was different for different age groups. Table 7 shows $F=16.612$ and $p<0.05$. This reveals that according to age groups, the group means are statistically significantly different at the level of 0.05 in the case of consumer satisfaction with warranty claim procedure. It indicates that hypothesis (H1) is rejected. Therefore, it can be considered that there is a significant difference in consumer satisfaction with warranty claim procedure with respect to age. It has been observed that younger Czech consumers are more satisfied with warranty claim procedure than aged consumers. One of the possible reasons for the finding is that younger respondents may be well aware of the warranty claim procedure from media - advertisements, cautious and sensitive towards a purchase.

ANOVA was run to determine if consumer satisfaction with warranty claim procedure was different for different level of education achieved. Table 7 presents $\mathrm{F}=7.324$ and $\mathrm{p}<0.05$. This means that according to the highest level of education achieved groups, the group means are statistically significantly different at the level of 0.05 in the case of consumer satisfaction with warranty claim procedure. It implies that hypothesis (H2) is rejected. Thus, it can be considered that there is a significant difference in consumer satisfaction with warranty claim procedure with respect to highest level of education achieved. It has been observed that Czech consumers with a higher education level are less likely to be satisfied with warranty claim procedure. A possible explanation for the finding is that consumers with higher education level may be less responsive to warranty claim procedure and do not find it worth of time and effort.

ANOVA was conducted to determine if consumer satisfaction with warranty claim procedure was different for different 'net household income per single person /month' groups. Table 7 shows $\mathrm{F}=0.064$ and $\mathrm{p}>0.05$. This reveals that according to 'net household income per single person /month' groups, the group means are not statistically significantly different at the level of 0.05 in the case of consumer satisfaction with warranty claim procedure. It indicates that hypothesis $(\mathrm{H} 3)$ is accepted. Therefore, it can be considered that there is no significant difference in consumer satisfaction with warranty claim procedure with respect to net household income per single person /month. In other words, for Czech consumers, there is no difference among customers having different 'net household income per single person /month' with regard to consumer satisfaction with warranty claim procedure. One of the possible reasons for the finding is that consumers in the Czech Republic belonging to any income groups can claim the warranty for purchases (within warranty period) without any difficulty as there is no (monetary) cost of claiming the warranty.

Table 8. Results of independent-samples t-test

\begin{tabular}{lccc}
\hline Hypothesis & $\mathrm{t}$ value & $\mathrm{p}$ value & Results \\
\hline Gender & -0.896 & $>0.05$ & Accepted \\
\hline
\end{tabular}

Source: authors' research.

The results of independent-samples t-test are shown in Table 8. An independent-samples $\mathrm{t}$-test was run to determine if there were differences in consumer satisfaction with warranty claim procedure between females and males. Table 8 shows $t=-0.896$ and $p>0.05$. This means that there is statistically no significant difference (at the level of 0.05) in consumer satisfaction with warranty claim procedure between females and males. It implies that hypothesis (H4) is accepted. Thus, it can be considered that there is no significant difference in consumer satisfaction with warranty claim procedure with respect to gender. In other words, for Czech consumers, there is no difference between genders with regard to consumer satisfaction with warranty claim procedure. One of the possible explanations of the finding can be attributed to 
the fact of equal exposure of knowledge and market for both male and female in the Czech Republic.

The results of this article will help management and marketing practitioners to formulate strategies for effective handling as well as management of consumers' warranty claims. In the context of our findings, young and lower education group consumers are more likely to be satisfied with warranty claim procedure. Hence, it is recommended to business entities to handle and resolve these consumers' warranty claims more sensitively, promptly and efficiently. With reference to our results, older and highly educated consumers are less likely to be satisfied with warranty claim procedure. Consequently, it is recommended to familiarise them with the effectiveness of warranty claim procedure and encourage them to seek redress and claim the warranty for purchases. To turn their dissatisfaction into satisfaction and earn their trustconfidence, their warranty claims issues should be treated more seriously and solved as quickly as possible. For a better understanding of consumers' warranty claims intentions and effective handling as well as management of those claims, the article suggests business organisations to consider their consumers' essential demographic characteristics and analyse them accordingly. Generalisations based on the findings of this research are limited and impact might not be same over European Union (EU).

\section{Conclusion}

In conclusion, the study program has provided information and insights on behaviour of Czech consumers concerning warranty claim. From the past two years' frequency of claimed goods or services based on warranty, it can be inferred that respondents have a positive tendency towards the warranty claim procedure. Interestingly, it was observed respondents purchasing a minimum value of $500 \mathrm{CZK}$ would proceed for the warranty claim procedure. However, there was a good percentage of respondents who would proceed for the warranty claim procedure irrespective of the minimum amount of goods being purchased. Among the respondents, most of them would rely on internet and family, friends or relatives' experiences to acquire information about the warranty claim procedure. At the same time, it can be inferred, respondents would likely opt for the money back option apart from exchange of goods for new ones as preferred mode for settling warranty claims. Moreover, younger consumers tend to be more satisfied with warranty claim procedure whereas, with a higher education level consumers intend to be less likely who are satisfied with warranty claim procedure. For both gender and customers having different 'net household income per single person /month' categories, no difference was observed with regard to consumer satisfaction with warranty claim procedure. This study will be useful to marketing theories and practices in enterprises.

\section{Acknowledgement}

Authors would like to thank the Faculty of Management and Economics at Tomas Bata University in Zlin. This work was supported by the Internal Grant Agency of Tomas Bata University in Zlin under project number IGA/FaME/2016/006.

\section{References}

Andreasen, A. R. (1988). Consumer complaints and redress: What we know and what we don't know. The frontier of research in the consumer interest, 675, 722.

Baker, T. L., Meyer, T., \& Chebat, J.-C. (2013). Cultural impacts on felt and expressed emotions and third party complaint relationships. Journal of Business Research, 66(7), 816-822. 
Boote, J. (1998). Towards a comprehensive taxonomy and model of consumer complaining behaviour. Journal of Consumer Satisfaction, Dissatisfaction and Complaining Behavior, $11,140-151$.

Broadbridge, A., \& Marshall, J. (1995). Consumer complaint behaviour: the case of electrical goods. International Journal of Retail \& Distribution Management, 23(9), 8-18.

Casado, A. B., Nicolau, J. L., \& Mas, F. J. (2011). The harmful consequences of failed recoveries in the banking industry. International Journal of Bank Marketing, 29(1), 3249.

Chan, G. S. H., Hsiao, A. C.-H., \& Lee, A. L. Y. (2016). Exploration of Customer Compliant Behavior toward Asain Full-Service Restaurants. International Journal of Marketing Studies, 8(2), 46.

Day, R. L. (1976). Collecting comprehensive consumer compliant data by survey research. NAAdvances in Consumer Research Volume 03.

Day, R. L. (1977). Extending the concept of consumer satisfaction. NA-Advances in Consumer Research Volume 04.

Ekinci, Y., Calderon, J., \& Siala, H. (2016). Do personality traits predict'complaining'consumers? International Journal of Business Environment, 8(1), $32-42$.

Garín-Muñoz, T., Pérez-Amaral, T., Gijón, C., \& López, R. (2016). Consumer complaint behaviour in telecommunications: The case of mobile phone users in Spain. Telecommunications Policy, 40(8), 804-820.

Grougiou, V., \& Pettigrew, S. (2009). Seniors' attitudes to voicing complaints: a qualitative study. Journal of Marketing Management, 25(9-10), 987-1001.

Hansen, T., Wilke, R., \& Zaichkowsky, J. (2010). Managing consumer complaints: differences and similarities among heterogeneous retailers. International Journal of Retail \& Distribution Management, 38(1), 6-23.

Haron, S., \& Paim, L. (2008). How mature consumers handle unpleasant experience in the market. Malaysian Journal of Consumer and Family Economics, 11, 85-94.

Heung, V. C. (2000). Satisfaction levels of mainland Chinese travelers with Hong Kong hotel services. International Journal of Contemporary Hospitality Management, 12(5), 308315.

Heung, V. C., \& Lam, T. (2003). Customer complaint behaviour towards hotel restaurant services. International Journal of Contemporary Hospitality Management, 15(5), 283289.

Hogarth, J. M., English, M., \& Sharma, M. (2001). Consumer complaints and third parties: Determinants of consumer satisfaction with complaint resolution efforts. Journal of Consumer Satisfaction, Dissatisfaction and Complaining Behavior, 14, 74.

Horáková, M. (2015). Consumer Behavior of College Students in the Czech Republic. Journal of Competitiveness, 7(4), 68-85. doi http://doi.org/10.7441/joc.2015.04.0

Huppertz, J. W. (2003). An effort model of first-stage complaining behavior. Journal of Consumer Satisfaction, Dissatisfaction and Complaining Behavior, 16, 132.

Jacoby, J., \& Jaccard, J. J. (1981). The sources, meaning, and validity of consumer complaint behavior: A psychological analysis. Journal of retailing.

Jin, L. (2010). Determinants of customers' complaint intention: empirical study in the context of China's retail industry. Nankai Business Review International, 1(1), 87-99.

Kanousi, A. (2005). An empirical investigation of the role of culture on service recovery expectations. Managing Service Quality: An International Journal, 15(1), 57-69.

Keng, K. A., Richmond, D., \& Han, S. (1995). Determinants of consumer complaint behaviour: a study of Singapore consumers. Journal of International Consumer Marketing, 8(2), 5976. 
Li, M. (2010). Exploration of Chinese consumer complaint behavior in the hospitality industry.

Liu, R. R., \& McClure, P. (2001). Recognizing cross-cultural differences in consumer complaint behavior and intentions: an empirical examination. Journal of consumer marketing, 18(1), 54-75.

Mahayudin, N. H. M., Haron, S. A., \& Yin-Fah, B. C. (2010). Unpleasant market experience and consumer complaint behavior. Asian Social Science, 6(5), 63.

Mattila, A. S., \& Wirtz, J. (2004). Consumer complaining to firms: the determinants of channel choice. Journal of Services Marketing, 18(2), 147-155.

Metehan, T., \& Zengin, A. Y. (2011). Demographic characteristics and complaint behavior: An empirical study concerning Turkish customers. International Journal of Business and Social Science, 2(9).

Moliner Velázquez, B., Fuentes Blasco, M., Gil Saura, I., \& Berenguer Contrí, G. (2010). Causes for complaining behaviour intentions: the moderator effect of previous customer experience of the restaurant. Journal of Services Marketing, 24(7), 532-545.

Ngai, E. W., Heung, V. C., Wong, Y., \& Chan, F. K. (2007). Consumer complaint behaviour of Asians and non-Asians about hotel services: an empirical analysis. European Journal of Marketing, 41(11/12), 1375-1391.

Nimako, S. G., \& Mensah, A. F. (2012). Motivation for customer complaining and noncomplaining behaviour towards mobile telecommunication services. Asian Journal of Business Management, 4(3), 310-320.

Oly Ndubisi, N., \& Yin Ling, T. (2006). Complaint behaviour of Malaysian consumers. Management Research News, 29(1/2), 65-76.

Phau, I., \& Baird, M. (2008). Complainers versus non-complainers retaliatory responses towards service dissatisfactions. Marketing Intelligence \& Planning, 26(6), 587-604.

Schiffman, L. G., \& Kanuk, L L. (2000). Consumer behavior, 7th. NY: Prentice Hall.

Shaw, S. (2017, April). Consumer complaint behaviour, warranty and warranty claim: brief overview. Paper presented at the DOKBAT $13^{\text {th }}$ Annual International Bata Conference. Zlín, Czech Republic.

Singh, J. (1988). Consumer complaint intentions and behavior: definitional and taxonomical issues. The journal of Marketing, 93-107.

Singh, J. (1989). Determinants of consumers' decisions to seek third party redress: An empirical study of dissatisfied patients. Journal of Consumer Affairs, 23(2), 329-363.

Swanson, S. R., Frankel, R., Sagan, M., \& Johansen, D. L. (2011). Private and public voice: exploring cultural influence. Managing Service Quality: An International Journal, 21(3), 216-239.

Tronvoll, B. (2007). Complainer characteristics when exit is closed. International journal of service industry management, 18(1), 25-51.

Volkov, M., Harker, D., \& Harker, M. (2002). Complaint behaviour: a study of the differences between complainants about advertising in Australia and the population at large. Journal of consumer marketing, 19(4), 319-332.

Williams, T. G. (2002). Social class influences on purchase evaluation criteria. Journal of consumer marketing, 19(3), 249-276. 